\title{
Assessment Of Political Literacy Among Female Students At The University Of Balochistan
}

\author{
Rubeena Batool \\ Department of Gender and Development Studies \\ University of Balochistan \\ Musarrat Jabeen \\ Department of International Relations \\ National Defense University
}

\begin{abstract}
Political literacy is sited at the periphery of political empowerment designs the real driver for good governance. This paper assesses the prevalence of political literacy based on political knowledge-attitude-practice among the female students in the University of Balochistan. We used KAP (knowledge-attitude-practice) analysis method to create the primary data. The qualitative factors analysis allow us to deduct the decline in the strength of political literacy when it moves from thought to action; sequenced as political knowledge factor found $79 \%$, political attitude factor found $58 \%$, and political practice factor found $34 \%$. The paper suggests that political literacy higher in knowledge and least in practices warrants the ineffectiveness of legally granted political empowerment to women in Balochistan. The policy makers may utilize this study for the effective women's political empowerment to achieve good governance vis-à-vis incurring economic development in and around Balochistan.
\end{abstract}

Keywords: Political Literacy, Women's Political Empowerment, Good Governance.

$$
\begin{aligned}
& \text { تلخيص }
\end{aligned}
$$

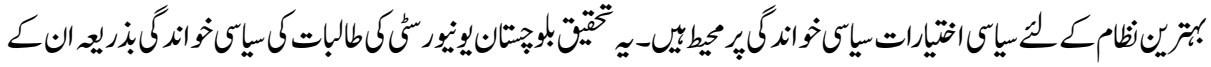

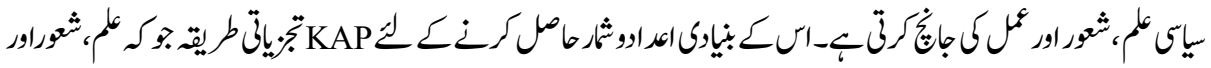

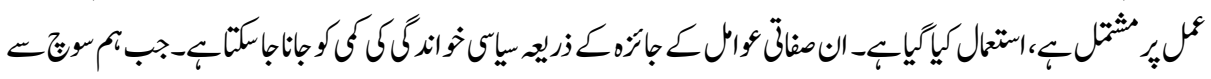

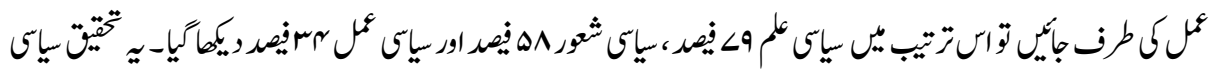

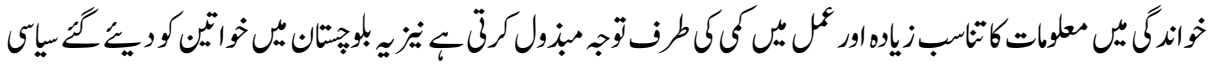

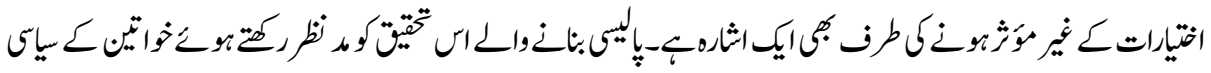

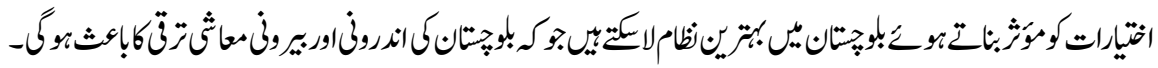

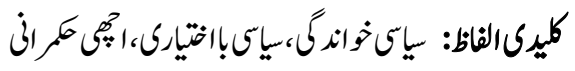




\section{Introduction}

"The worst illiterate is the political illiterate, he doesn't hear, doesn't speak, nor participates in the political events. He doesn't know the cost of life, the price of the bean, of the fish, of the flour, of the rent, of the shoes and of the medicine, all depends on political decisions. The political illiterate is so stupid that he is proud and swells his chest saying that he hates politics. The imbecile doesn't know that, from his political ignorance is born the prostitute, the abandoned child, and the worst thieves of all, the bad politician, corrupted and flunky of the national and multinational companies." Bertolt Brecht ${ }^{1}$

Governance indicates the relationship between the governing and the governed regarding the resource management for collective good. Political literacy is resourceful sensibility to stage good governance referred to political empowerment comprised of political policies and political practices. We focus on political literacy (as practice) intensity in women after the increased women representation (as policy) in the political institutions of Pakistan-Balochistan since 2001. The individuals and groups feel empowered when they can work for \& earn their social benefits and economic needs. This notion of empowerment is most of the time challenged while contested in different contexts in different ways by women particularly. The women are found dependent on normative power patterns of informal and formal institutions which impact their political empowerment. Legal empowerment of women is enabling factor to bring forth the change in prevalent political format of a society. We choose to assume the perspective of women empowerment based on socio-political process and association between political policy and practice by assessing the political literacy among female students in the University of Balochistan.

Post 9/11 Gender development literature focuses political development in Balochistan. Military operations were launched in different areas of Pakistan. Balochistan is one of the provinces where the consequences of these operations can be clearly seen, researches were found that address women issues related to armed conflict, security discourse in post 9/11 Pakistan-Balochistan (Rashid, 2009). Women empowerment in Balochistan through devolution plan 2001 is indicator of political development of Balochistan (Javed \& Khan, 2006). "Women's Empowerment in Challenging Environments: A Case Study from Balochistan"(Pterson, 2008) the article offers policies for women empowerment in traditional, ethnic, and religious setting. "Economic empowerment of women in the rural areas of Balochistan: World System analysis at Micro level in Anthropological perspective" (Mohyuddin, Anwaar, Rehamn, Umbreen, \& Mamonah, 2012), "Problems and Challenges Faced by the Rural Women: A Case Study of Balochistan" (Khoso, Shafique, Abidi, \& Shaikh, 2011) 
Researches on Pakistan local government system with reference to women political empowerment in Balochistan illustrate the process, number of women representatives, quota systems under the Musharraf Regime" (Graff, 2003). Jabeen \& Iqbal (2010) issues related to women as councilors, and how the socio cultural norms and practices disregard gender development initiatives.

A report titled "Women Representation in Local Government in Pakistan: Impact Analysis and Future Policy Implications" by Yazdani, (2004) found obstacles in local government policy 2001; voters political literacy as capacity to make coherent choices, and decisions when voting and political freedom as the independent decision to vote or not.

To highlight political education of female voters NGOs reports emphasized on voter registrations, CNIC provision and mobilize them to cast vote. ${ }^{2}$ Another focus of NGOs is to educate the elected representatives about their roles and duties. ${ }^{3}$ We have done searches in both printed and on-line media and have not come across any similar work to Political Literacy among Female Students in the University of Balochistan.

As above facts it is assumed that political literacy promotes informed political participation. The study attempts following questions:

1. What is the significance of relationship between women political empowerment and political literacy?

2. What is informed political participation?

3. What is level of political knowledge among female voters?

4. How are the political attitudes among female voters?

5. What are the political practices among female voters?

This paper presents the general picture of policy based women's political empowerment of Pakistan as indicating factor of good governance. The research covers discussions on political literacy among the females based on knowledge, attitude and practices as determining factor of women's political empowerment. This study will help to develop informed political participation patterns.

\section{Literature Review}

Kaufman et al (2005) have noted that governance fashions a people to express interests, reconcile the differences and exercise the legal rights and duties. The World Bank (2004) counts empowerment of individuals and groups is to act upon the socio-economic desires for actual results. Cleaver (1999) found non clarity of empowerment; that how it can be related to different categories of people and groups particularly to women. Kothari (2001) established empowerment as the intensity of likelihood of an individual in a particular social context to promote his/her position. Batiwala (2007) estimated the empowerment is to change the socio-economic power process existing in a society. 
Power is central to any conceptualizations of empowerment, and is at the very root of the term itself. In perspective of feminism Amy Allen stated that, " feminists who conceptualize power as empowerment do of course acknowledge that, in patriarchal societies, men are in a position of dominance over women; but they choose to focus on a different understanding of power, power as the ability to empower and transform oneself, others, and the world" (1999). Srilatha, Batiwala proposes that women's empowerment involves challenging patriarchal relations, which in turn requires that women first recognize the ideology that legitimizes male domination and understand how it perpetuates their oppression. She further stated that this process of change does not necessarily begin spontaneously from the condition of subjugation; it must be 'extremely induced'. She claims, "Women must be convinced of their innate right to equality, dignity and justice” (1994).

Feminism had a strong connection with women's political empowerment. Modern feminist movements were originated with the cause of women's political rights. These movements were divided into three waves. First wave refers mainly to women's suffrage movements of the 19th and early 20th centuries in Great Britain and United States. During this movement activists focused on gaining women's political power by given them right to vote. In Britain 1918 Act under the representation of people was passed granting the vote to women over the age of 30 and those who owned houses. Than in 1928 it was extended to all women over 21 years of age. In United States under the 19th amendment to the constitution in 1919, granting women the right to vote in all states.

Women's movement activism in recent years has inspired feminists for at least two additional meanings of empowerment. One group expands its range to encompass informal politics and the dynamics of everyday life. Some scholars insist, for example, that social movements are a form of political participation at par with engagement inside the state (Baldez, 2002; Beckwith, 2007). The other group has adopted a notion of "politics" as any instance and or manifestation of power relations. They are not interested only in the politics of state and the politics of social movements but also the politics of language, the politics of exchange and the politics of representation (Krook and Childs, 2010).

Increased globalization, combined decentralization has posed major challenges to traditional configurations of political organization, creating new opportunities and constraints for feminist change. As a consequence, "politics" is now an even more diffuse entity, with new and developing arrangements that are not yet well understood. It is also observed by feminists that with women's overall rates of education and labor force participation (McDonagh, 2002) as well as with levels of national socioeconomic development (Matland, 1998), attributed to modernization processes move into higher social and economic roles lead to greater influence in politics (Inglehart and Norris 2003).

There is an ongoing debate regarding the nature and importance of the gender gap in voting behavior. In addition to asking why women as a group might have political 
preferences distinct from those of men (Studlar, McAllister and Hayes, 1998), scholars have probed the content of women's political interests (Campbell, 2006) and sought to explain lower levels of political knowledge among women as compared to men, despite changes in the opportunities for women's engagement in political life (Mondak and Anderson, 2004). Inclusion of women into formal politics to engender democracy, a big challenge for feminists has to develop a distinct political community of women and to articulate interest in and around gender-based injustices (Cornwall and Geotz, 2005). Another fundamental point in feminist view on the politics of women's representation is that differences among women, such as class, race, ethnicity, generation etc. have great impact on their interests and priorities (Lovenduski, 2000).

This paper presents the general picture of policy based women's political empowerment of Pakistan as indicating factor of good governance. The research covers discussions on political literacy among the females based on knowledge, attitude and practices as determining factor of women's political empowerment.

\section{Good Governance}

UN Secretary-General Kofi Annan noted that "good governance is perhaps the single most important factor in eradicating poverty and promoting development". Good governance bases on understanding of organizational structure and its performance. The organizational structure includes the arrangements of stated purpose, rules of governance, transparency and accountability in the diversity of contexts. Good governance referred by the WB deal with economic institutions and public sector in contact to regulation and accountability. Various project sponsors include election monitoring, political party support, combating corruption, building independent judiciaries, security sector reforms, decentralization, civil and political rights, and government responsiveness (Gisselquist, 2012). The evidence suggests that good governance is a process indicating the ability of a country's governance institutions to build power, share trust, and information throughout society.

\section{Women's Political Empowerment}

The representation of women in politics and their right to vote is termed as political empowerment (Lodigiani \& Salomone, 2015). Konadu (2001) accords his concern that the state of women's participation in politics and public decision-making is disappointing. Men have always monopolized and dominated decision-making positions. Constituting almost half of the world's population and making half of the electorate, women do have an important role to play in politics. Despite dramatic global change in women's political representation (Paxton et al. 2006) low percentage of women exercise their right to vote (women suffrage) that is detrimental to good governance (Farood, 2003). The national context of Pakistan is favorable to women's participation in governance. It can be referred as policy and practice based women's political empowerment. 
Since 1973 Constitution, increase in women's representation has been observed, initially 10 seats were reserved for females in the National Assembly, in the era of General Zia (19771988) seats doubled for females, General Musharaf (1999-2007) in his time increased the number of women's seats in the National Assembly to an impressive number of 60 out of total 342. Local Government level: in the first local bodies elections held in 1959 under the military dictatorship of General Ayub Khan, women were not given any representation. However, in the subsequent Local Government Ordinances of Punjab (1979), NWFP (1979), Sindh (1979) and Balochistan (1980) seats were reserved for women in local bodies. Since $200133 \%$ high visibility of women in the local government system raised public interest and debate on the effectiveness of women's representation.

Women right to vote initiated with the foundation of Pakistan in 1947. Despite this fact, women are found not practicing their right to vote; reason being the socio-political culture of the country. Due to in vogue patriarchal ideologies, women themselves do not consider politics as their legitimate sphere. Politics is generally perceived by women as 'dirty practice'. The gender divide shapes public perception of politics as a male arena. Because of social perception of women's primary roles as mothers and wives in the reproductive sphere, the family and society least bothers to strengthen women with social construct in political terms. Women's subordinate position in the family and society is the key ideological barrier to women's political participation in local governance. Women are not given equal access to opportunities and resources which results in their dependent social and economic status vis-à-vis men. Women in general do not have educational qualifications, independent financial means or social capital to enter into politics. Equality of women in politics is not on any party's agenda. They are content with flaunting their few women leaders as evidence of their progressive politics.

It is found that the shortcoming to effectuate devolution plan 2001 to enhance women political empowerment was the failure to recognize, acknowledge and accurately define the surrounding environment, including not only the policy making but also the political, informational, social, cultural, religious, and economic elements of the environment. The ground level economic, social, cultural, psychological, and ethical dynamics determine the political empowerment among the gender patterns of society, and society/state political relationship. These dynamics arise as salient features before/during/after election scenarios. Policy making to empower women politically is important factor but the political literacy defined in terms of political knowledge, attitude and practice affecting outcomes must be grappled.

\section{Political Literacy}

Political literacy is a major determining factor of practice based political empowerment. Political literacy is potential to understand the political processes vis-à-vis ideas of social needs; it implies the ability and willingness to use political expertise in functional manner to participate in society for good governance. 
This paper utilizes cognitive mobilization theory of political literacy, conceptualized as the potential for political participation. Education and political involvement mobilize political literacy as an internal process. The theory dominates says that education and political involvement act upon the individual to mobilize his or her mental capabilities dealing with politics. Campbell et al (1960) reported, "The education process is one in which individuals are constantly selected for passage to higher levels on the basis of existing intellectual capacities. It is the purpose of education to develop these capacities, so that a person who moves to higher levels is likely to employ different modes of thought in evaluating objects than someone of equal initial capacity. Sufficient involvement in politics may act as a fair surrogate for education in providing more efficient modes of organizing political perceptions".

Political literacy can be measured regarding understanding party differences, basic political concepts and facts. Erikson et al, (1995) pointed out, "Electorate must be informed to maintain popular control, political literacy is central to empirical theories of democracy." Westholm et al (1990) defined political literacy as "the basic concepts and facts that constitute a necessary condition for comprehending the contents of public debate." Denver and Hands (1990) defined political literacy as "the knowledge and undertaking of the political process and political issues which enables people to perform their roles as citizens effectively." Political literacy is the potential for informed political participation. Krosnick (1990) called this concept "political expertise," and Zaller (1992) called it "political awareness," the extent to which an individual pays attention to politics and understands what he or she has encountered."

\section{Education Mobilizes Political Literacy}

To show case education as potential for political participation the Multiple Indicator Cluster Survey (MICS) results are relied for this paper (see Table 1) established in 2004 by UNICEF in collaboration with the government of Pakistan. 27\% population of Balochistan is literate. Literacy rate found highest in the capital city of Balochistan; Quetta Zarghoon (59\%)/Quetta Chiltan (49\%) and established least (below 20\%) in Dear Bugti, Musa Khail, Kohlu, JhalMagsi. The results are particular to this research design because; 15-24 years of age is recommended for MDG's and Education for All (EFA), this age group is more responsive to changes in education scenarios spurred by global practices through international institutions transcending national borders effecting literacy of local population and they reside in urban area. 
Table: 1

Literacy Rate for 10 years and above

\begin{tabular}{|l|c|c|c|}
\hline & Balochistan & Urban & Rural \\
\hline Male & 39 & 65 & 33 \\
\hline Female & 16 & 40 & 10 \\
\hline Total & 28 & 54 & 23 \\
\hline
\end{tabular}

Source: Literacy \& Education-Government of Balochistan, available on http://www.balochistan.gov.pk/mics/MICS-4-Web/4-1-Results-

Literacy\%20\&\%20Education.pdf, accessed on Nov 22, 2016

\section{Political Involvement Mobilizes Political Literacy}

In this paper political involvement initials with the political concepts and facts in contact to federal form of government, political party system, vision \& mission of political parties, general and local bodies elections and female suffrage. It moves to political attitude identified as acquisition of CNIC, registration in voter's list, constituency to vote, and the interest in political issues and debates. It describes political practice as knowing the trends of female voters to vote in general and local body elections, to persuade others to vote in the elections and the willingness to participate in political campaigns and debates in future.

The purpose of the study is to highlight the practices based women's political empowerment for good governance. The specific objectives are as follows:

1. To assess the prevalence level of political literacy in the female students of University of Balochistan, Quetta

2. To make out the gap among the three stages of political literacy identified as political knowledge, attitude and practice.

\section{Methodology}

The methods applied in this research are:

- Analytical; for securing knowledge from secondary data documented in books, journals, and reports or printed online sources of knowledge

- Empirical; for generating primary data by using structured questionnaire

\section{Conceptual Framework to Assess Political Literacy among Female Students of University of Balochistan}

Political literacy may not be conditioned only with the political expertise but it is contextual to social construct of political behavior. Collective endorsement of political 
literacy vital for women's political empowerment proved by casting informed vote or participating in discussions and activities on public issues.

The conceptual framework of this research deals with prevalence of political literacy. (see Fig. 1).

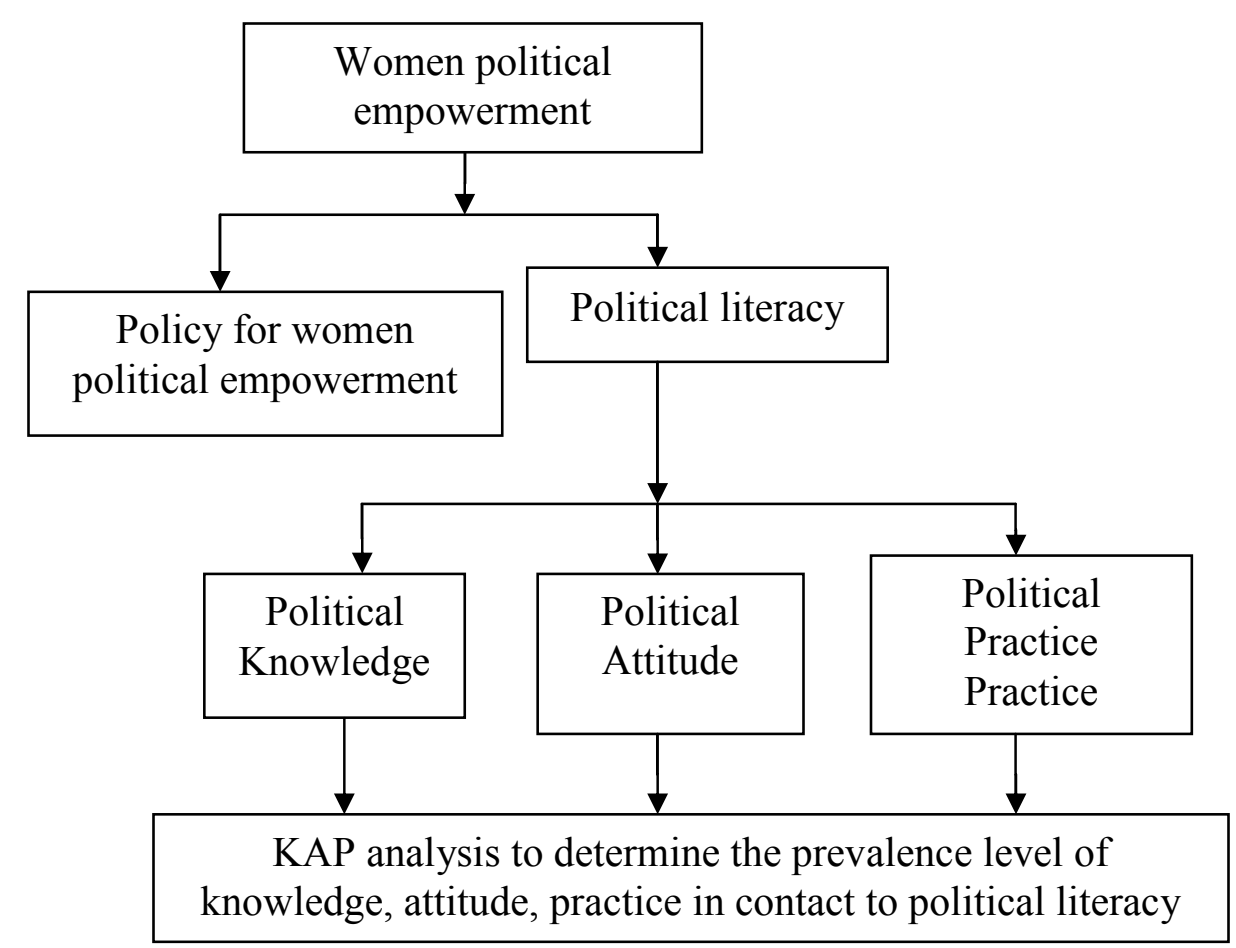

Source: self-extract

Fig.1: Conceptual framework to determine the correlation between women political empowerment and political literacy

\section{Methods of Data Collection}

Human behavior persists diversely to respond different challenges as per their societal and personal dispositions in contact to political empowerment. The design of this study tries to assess the level of prevalence of knowledge, attitude, and practice in contact to political literacy. By Consisting three components KAP activity was held in August, 2016.

\section{Questionnaires}

The designed questionnaire focuses practice based women's political empowerment. The information secured by serving this questionnaire looks innovative to be added in the 
secondary data. The questions move from thought to action to get the set objectives for this study. The facts tabled in this study are based on responses to questions.

In total, 140 females students were chosen by purposive sampling to assess the political literacy in University of Balochistan. Equally 70 respondents were selected from sciences and social sciences faculties. The structured questionnaire is composed of three stages of political literacy: political knowledge, political attitude and political practice (see Annexure 1).

\section{Observations}

Data collected through structured questionnaires was corroborated on the basis of personal observations.

\section{Data Analysis}

Data was analyzed by dilating frequency distribution to tabulate average as mode of each section.

\section{Findings and Analyses}

The guiding principle to design this research was: the policy based women's political empowerment cannot lead to good governance, but must be driven by political literacy mobilized through political education and involvement. It is found that legal political empowerment cannot work without the support of social power patterns comprising formal and informal institutions. Likewise the general or formal education to promote political expertise cannot empower the women politically unless they have the political literacy determined by the willingness of women to become the active part of decision making for collective good. Political empowerment is the real strength for good governance is shaped by the prevalence of political literacy. An informed electorate is the prerequisite of democratic practices. Political literacy capacitates the citizens to express their interests, reconcile their differences and work out their legal rights and obligations. The study describes the findings in deductive style under three headings.

\section{Political Knowledge}

The study estimated the political knowledge of the respondents assuming that the existence of particular knowledge may help to show better attitude. The type of political knowledge measured is correlated to their political awareness as per acquired through the knowledge provided in the formal and informal institutions (see Table 1). 
Table: 1

Prevalence level of political knowledge

\begin{tabular}{|l|l|c|c|}
\hline & Tell us your understanding of the political concepts and facts. & Yes & No \\
\hline K1 & In Pakistan we have federal form of government. & $70 \%$ & $30 \%$ \\
\hline K2 & In Pakistan ruling party is "Muslim League N." & $89 \%$ & $11 \%$ \\
\hline K3 & $\begin{array}{l}\text { In Pakistan "Pakistan Tehrike Insaf" pledges to change the } \\
\text { political dynamics of society. }\end{array}$ & $66 \%$ & $34 \%$ \\
\hline K4 & In Pakistan general elections are held after every five years. & $92 \%$ & $8 \%$ \\
\hline K5 & $\begin{array}{l}\text { In Pakistan local government elections are held after every five } \\
\text { years. }\end{array}$ & $59 \%$ & $41 \%$ \\
\hline K6 & $\begin{array}{l}\text { In Pakistan every male and female of 18 years age have right to } \\
\text { vote except Gilgit Baltistan. }\end{array}$ & $96 \%$ & $4 \%$ \\
\hline
\end{tabular}

The study finds the highest content of political knowledge of $79 \%$ as compared to political attitude and political practice. It deduces that $70 \%$ of respondents know that Pakistan has federal form of government because frequently people talk about center province relations. While $89 \%$ population knows Pakistan Muslim League is ruling the country because media repeats this fact time and again. People lack the knowledge regarding vision of political parties that's why only $66 \%$ know that Tehrik e Insaf pledges to change. People know more about general elections than the local elections; the results tell us $92 \%$ people know about general elections are held after every five years while 59\% claim to know the local bodies elections after every five years. $96 \%$ respondents know that they have the right to vote; interestingly only $4 \%$ sounded the negative.

\section{Political Attitude}

Mental involvement in political knowledge turns into political attitude based on political perceptions and experience encountered in the political environment of a society. It is likely that a person with political knowledge gets ready to express his/her political behavior. This likelihood is measured by this study by putting four questions to the respondents (see Table 2)

Table: 2

Prevalence level of political attitude

\begin{tabular}{|l|l|c|l|}
\hline & Tell us that you reflect political concepts and facts in your attitude & YES & NO \\
\hline A1 & Did you acquire your CNIC in order to cast a vote? & $83 \%$ & $17 \%$ \\
\hline A2 & Are you registered in the voter's list? & $60 \%$ & $40 \%$ \\
\hline A3 & Do you know your constituency to vote in elections? & $40 \%$ & $60 \%$ \\
\hline A4 & Do you take interest in discussions or debates about political issues? & $48 \%$ & $52 \%$ \\
& & & \\
\hline
\end{tabular}

The political attitude stood second in overall results of the study that is $58 \%$ compared to $79 \%$ of political knowledge and $34 \%$ of political practice. $83 \%$ population acquired the 
CNIC to vote that is encouraging. Nonetheless they secured the CNIC but only $60 \%$ know that their name is in voter's list; it is deduced that they are not committed to vote because they cannot vote if their name is not in the voter's list. More so they do not realize that if they do not know their constituency; they cannot vote. The results indicate regarding question 3 only $40 \%$ respondents know their constituency while the $60 \%$ response is found negative. It is likely that the respondents as voters will behave irrationally for choosing right political leadership because they do not take interest in political debates on certain socio-political issues. It is established by the study that only $48 \%$ females take interest in political discussions.

\section{Political Practice}

Political knowledge and political attitude shapes the political practice of the electorate depending on the status of the voter in a society and her will to function as concerned citizen to contest the ideas of social needs in political processes. Mostly it is assumed that the education sources political empowerment but this study found the political empowerment in real terms only $34 \%$ the least output compared to the $79 \%$ political knowledge and 58\% political attitude (see, Table 3 ).

\section{Table: 3}

Prevalence level of political practices

\begin{tabular}{|c|c|c|c|}
\hline & $\begin{array}{l}\text { Tell us the practices you opt to reflect your political knowledge and } \\
\text { political attitude. }\end{array}$ & Yes & No \\
\hline P1 & Did you vote in 2013 general elections of Pakistan? & $19 \%$ & $81 \%$ \\
\hline P2 & $\begin{array}{l}\text { Did you persuade others to vote in } 2013 \text { general election of } \\
\text { Pakistan? }\end{array}$ & $16 \%$ & $84 \%$ \\
\hline P3 & Did you vote in 2013 local government elections of Balochistan? & $14 \%$ & $86 \%$ \\
\hline P4 & $\begin{array}{l}\text { Did you persuade others to vote in } 2013 \text { local government elections } \\
\text { of Balochistan? }\end{array}$ & $14 \%$ & $86 \%$ \\
\hline P5 & Do you participate in discussions/debates on political issues? & $14 \%$ & $86 \%$ \\
\hline P6 & $\begin{array}{l}\text { Are you interested in participation in political awareness campaigns } \\
\text { in future? }\end{array}$ & $24 \%$ & $76 \%$ \\
\hline
\end{tabular}

The study found only $19 \%$ of the respondents voted in the general elections of 2013 and even lesser in the local government elections as the results indicate only $14 \%$ voting trend in this perspective. The persuasion practice is found $16 \%$ in general and $14 \%$ in local government elections that indicates the less importance of local elections for the electorate. Only 14\% respondents participate in political discussions/debates and $24 \%$ are interested to participate in political campaigns in future. From this study it is pertinent to point out that formal education is not a benchmark to predict the political participation for empirical democracy. 
Data collected from the two categories of the students Sciences and Social Sciences. At the start of the study it was expected that in higher education students more political literacy would prevail, however primary data shows that political participation does not depend on political knowledge and political attitude but it depends on willingness to use political expertise in functional manner to participate in society for good governance, Table 3 confirms this premise.

\section{Conclusions and Recommendations}

The results of KAP survey conducted in the University of Balochisan found $67 \%$ political literacy (accumulative of knowledge, attitude and practice) among the female students. The decline analysis allow us to deduct the decline in the strength of political literacy when it moves from thought to action; sequenced as political knowledge found $79 \%$, political attitude found 58\%, and political practice found 34\% (see, Figure 2).

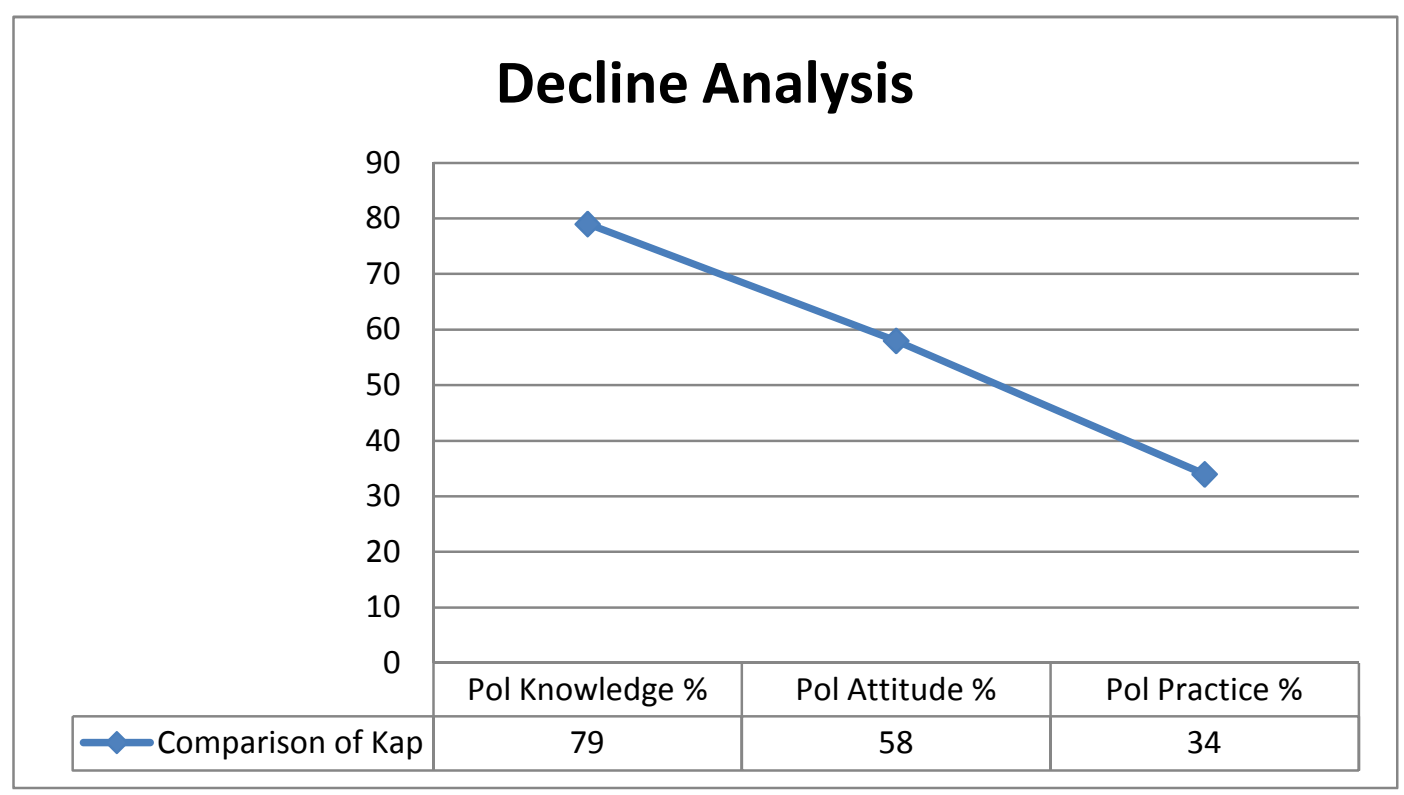

Fig 2

The social science students are found more responsive to the survey, it is suggested that social sciences should be taught to science students as well to become concerned citizens as everyone is driven and affected by political governance. The specific education regarding political literacy should be dispersed by conducting workshops, as formal education is found inadequate to nurture political know how in higher education students particularly the political attitude and practice. The outcome of this study is useful because it considers the female students of higher education the potential informal source of socio-political change to effectuate the women's political empowerment articulated as 
representatives and voters in the frameworks of formal institutions of national-provincial and local governance mechanisms.

The results of this study can be used to design a strategy for political literacy by more emphasis on political attitude and political practice that can be source of actual women's empowerment leading to good governance. Women's political empowerment styled for governance in Pakistan is developed by policymaking while society does not support women politicians because of reasons; they cannot become a politician as politics are considered for men, they are not financially independent, their role is mostly affiliated to men as wives, they fulfill the reproductive responsibility. Therefore political literacy has to be developed and dispersed to insinuate women in civil society to obvious women political empowerment in Balochistan. The study was conducted to describe the state of the art of political literacy among the female students of University of Balochistan. If the study is extended to different universities, and regions it may produce different results.

"It is not the most the strongest of the species that survive, nor the most intelligent, but the one most responsive to change." (Charles Darwin 1809-1882)

\section{End Notes}

1 https://www.biography.com/people/bertolt-brecht-92250281898-1956), accessed on Oct 21, 2017

2 Citizens Report of the Citizens Campaign for Women's representation in Local Government in Pakistan 2000-2001" by Aurat Foundation.

3 Leadership Development for Effective Women Councilors" by Aurat Foundation in 2003 And another report titled "performance of women parliamentarians in the $12^{\text {th }}$ national assembly: a five year report” (Mirza \& Agha, 2009)

\section{References}

Allen, A. (1999). The Power of Feminist Theory: Domination, Resistance, Solidarity. Boulder, CO: Westview Press.

Batiwala, S. (1994). The Meaning of Women's Empowerment: New Concepts from Action. Population Policies Reconsidered: Health, Empowerment and Rights.

Batiwala, S. (2007). Taking the Power out of Empowerment an Experiential Account, Development in Practice, vol.17:4-5, pp.557-565.

Beckwith, K. (2007). Numbers and Newness: The Descriptive and Substantive Representation of Women. Canadian Journal of Political Science, vol.40:1, pp.27-49. 
Bladez, L. (2002). Why Women Protest: Women's Movements in Chile. New York: Cambridge University Press.

Campbell, Angus, Converse, Phillip. E., Miller, Warren. E., \& Stokes, Donald. E. (1960). The New York Voter. Wiley.

Campbell, R. (2006). Gender and the Vote in Britain: Beyond the Gender Gap? Oxford: ECPR Press.

Cleaver, F. (1999). Paradoxes of Participation: Questioning Participatory Approaches to Development. Journal of International Development, vol.11, pp.597-612.

Cornwall, A., \& Geotz, A. M. (2005). Democratizing Democracy: Feminist Perspectives. Democratization, vol.12:5, pp.783-800.

Denver, David \& Hands, Gordon. (1990). Does Studying Politics Makes a Difference? The Political knowledge Attitudes and Perceptions of School Students. British Journal of Political Science, vol.20, pp.263-288.

Erikson, Robert, Kent, S. \& Tedin, L. (1995). American Public Opinion: Its Origin Content and Impact (5th ed.). Boston Allyn and Bacon.

Farood, M. (2003). PhD diss: Structural Transformation and Gender Empowerment in Pakistan. Bahauddin Zakariya University Multan.

Graff, I. (2003). Women Representation in Pakistan Politics, The Quota Systems under the Musharraf Regime. Ist International Conference on Women and Politics in Asia. Sweden.

Inglehart, R. \& Norris, P. (2003). Rising Tide: Gender Equality and Cultural Change Around the World. New York: Cambridge University Press.

Jabeen, N., \& Iqbal, Z. (2010). Gender and Local Governance in Pakistan: Promoting Participation through Capacity Building. Research Journal of South Asian Studies, 25(2), 255-281

Javed, S. \& Khan, A. (2006). Women Participation in New Local Government System and Its Impact on the Development of Balochistan. Journal of Applied and Emerging Sciences, vol.1:2. 
Kaufman, D., Kraay, A. \& Mastruzzi, M. (2005). Measuring Governance Using Cross Country Perception Data. The World Bank. http://www.worldbank.org/wbi/ governance/govdata/.

Khoso, I., Shafique, K., Abidi, A. R. \& Shaikh, M. (2011). Problems and Challenges Faced by the Rural Women: A Case Study of Balochistan. Asian Culture and History, vol.3:1.

Konadu, O. (2001). Gender Analysis and Interpretation of Barriers to Women Participation in Ghana Decentralized Local Government Systems. Paper Presented at African Gender Institute, university of Cape Town.

Kothari, U. (2011). Power Knowledge and Social Control in Participatory Development. London: ZED Books.

Krook, M. L. \& Childs, S. (2010). Women, Gender and Politics: A Reader. New York: Oxford University Press.

Krosnick, Jon Alexander. (1990). Expertise and Political Psychology. Social Cognition, vol.8, pp.1-8.

Lodigiani, E. \& Solomon, S. (2015) Migration Inducted Transfer of Norms: The Case of Female Political Empowerment, University Ca'Foscari of Venice, Department of Economics, Research Paper Series No.19.

Lovenduski, Joni (ed) (2000) Feminism and Politics, Volume II.

Matland, R. E. (1998). Women's Representation in National Legislatures: Developed and Developing Countries. Legislative Studies Quarterly, vol.23:1, pp.109-125.

McDonagh, E. (2002). Political Citizenship and Democratization: The Gender Paradox. American Political Science Review, vol.96:3, pp.535-552.

Mohyuddin, Anwaar, Rehman, H. u,. Umbreen, \& Mamonah. (2012). Economic Empowerment of Women in the Rural Areas of Balochistan. Pakistan Journal of Women Studies: Alam-e-Niswan, vol.19:2, pp.239-257.

Mondak, J. J. \& Anderson, M. R. (2004). The Knowledge Gap: A Reexamination of Gender-Based Differences in Political Knowledge. Journal of Politics, vol.66:2, pp.492-512. 
Multiple Indicator Cluster Survey (MICS) (2004). Balochistan available on http://data.org.pk/index.php?r=datasets\%2Fdetails\&data_set_id=187 accessed on November 19, 2016

Paxton, P., Huges MM. \& Green JL. (2006). The International Women's Movement and Women's Political Representation, 1893-2003. American Sociological Review, vol.71:6, pp.898-920.

Pterson, R. (2008). Women's Empowerment in Challenging Environments: A Case Study from Balochistan in Practice, vol.18:3, pp.333-344.

Rachel, Gisselquist (2012). What Does Good Governance Means? United Nations University

Rashid, T. (2009). Militarized Masculinities, Female Bodies and Security Discourse in Post 9/11 Pakistan. Strategic Analysis, vol.33:4.

Studlar, D. T., McAllister, I. \& Hayes, B. C. (1998). Explaining the Gender Gap in Voting: A Cross-National Analysis. Social Science Quarterly, vol.79:4, pp.779-798.

Westholme, Andres, Lindquist, A. \& Neimi, R. G. (1990). Education and Making of Informed Citizen: Political Literacy and the Outside World. Political Socialization, Citizenship Education and Democracy, vol.20:3.

World Bank (2004). Human Development, Social Development, Public Sector Management Network. Discussion Paper for International Local Development Conference. Wsashington DC: World Bank Publications.

Yazdani, F. (2004). Women's Representation in Local Government in Pakistan: Impact Analysis and Future Policy Implications. Budapest: Central European University.

Zaller, J. R. (1992). The Nature and Origins of Mass Opinion. Cambridge: Cambridge University Press. 


\section{Annexure: 1}

\section{Assessment of Political Literacy among Female Students in the University of Balochistan}

Questionnaire

This questionnaire is based on the 'Knowledge Attitude Practice' KAP analysis method.

\begin{tabular}{|l|c|}
\hline Social Sciences & Sciences \\
\hline \multicolumn{2}{|c}{ Section 'A' (Political knowledge) } \\
\hline Tell us your understanding of the political concepts and facts.
\end{tabular}

- In Pakistan we have federal form of government: Yes No

- In Pakistan ruling party is "Muslim League N.". Yes No

- In Pakistan "Pakistan TehrikeInsaf" pledges to change the political dynamics of society: Yes No

- In Pakistan general elections are held after every five years: Yeș No

- In Pakistan local government elections are held after every five years: Yeș No

- In Pakistan every male and female of 18 years age have right to vote except GilgitBaltistan: Yes No

Section 'B' (Political Attitude)

Tell us that you reflect political concepts and facts in your attitude.

- $\quad$ Did you acquire your CNIC in order to cast a vote? Yes No

- Are you registered in the voter's list? Yes No

- Do you know your constituency to vote in elections? Yes No

- Do you take interest in discussions or debates about political issues? Yeș No

Section ' $C$ ' (Political Practice)

Tell us the practices you opt to reflect your political knowledge and political attitude.

- Did you vote in 2013 general elections of Pakistan? Yes No

- Did you persuade others to vote in 2013 general election of Pakistan? Yes No

- Did you vote in 2013 local government elections of Balochistan? Yes No

- Did you persuade others to vote in 2013 local government elections of Balochistan? Yes No

- Do you participate in discussions/debates on political issues? Yeș No

- Are you interested in participation in political awareness campaigns in future? Yeș No

Rubeena Batool is Lecturer in the Department of Gender and Development Studies, University of Balochistan, Quetta, Pakistan.

Dr. Musarrat Jabeen is an Associate Professor in the Department of International Relations, Faculty Contemporary Studies, National Defence University, Islamabad, Pakistan. 